Check for updates

Cite this: RSC Adv., 2018, 8, 17312

Received 14th January 2018 Accepted 3rd May 2018

DOI: $10.1039 / c 8 r a 00409 a$

rsc.li/rsc-advances

\section{Shock response of condensed-phase RDX: molecular dynamics simulations in conjunction with the MSST method}

\begin{abstract}
$\mathrm{Ni}-\mathrm{Na} \mathrm{Ge}$, (D) *a Sha Bai, ${ }^{\mathrm{b}}$ Jing Chang ${ }^{\mathrm{c}}$ and Guang-Fu Ji ${ }^{\mathrm{b}}$
We have performed molecular dynamics simulations in conjunction with the multiscale shock technique (MSST) to study the initial chemical processes of condensed-phase RDX under various shock velocities (8 $\mathrm{km} \mathrm{s}^{-1}, 10 \mathrm{~km} \mathrm{~s}^{-1}$ and $11 \mathrm{~km} \mathrm{~s}^{-1}$ ). A self-consistent charge density functional tight-binding (SCC-DFTB) method was used. We find that the $\mathrm{N}-\mathrm{NO}_{2}$ bond dissociation is the primary pathway for RDX with the $\mathrm{NO}_{2}$ groups facing (group 1) the shock, whereas the $\mathrm{C}-\mathrm{N}$ bond scission is the dominant primary channel for RDX with the $\mathrm{NO}_{2}$ groups facing away from (group 2) the shock. In addition, our results present that the $\mathrm{NO}_{2}$ groups facing away from the shock are rather inert to shock loading. Moreover, the reaction pathways of a single RDX molecule under the $11 \mathrm{~km} \mathrm{~s}^{-1}$ shock velocity have been mapped out in detail, $\mathrm{NO}_{2}, \mathrm{NO}, \mathrm{N}_{2} \mathrm{O}, \mathrm{CO}$ and $\mathrm{N}_{2}$ were the main products.
\end{abstract}

\section{Introduction}

Energetic materials like RDX have rather a long history of interest because they have been widely used in both military and industry applications. One of the major objectives in the area of energetic materials is to reduce sensitivity to detonation initiated by unintentional external stimuli, for example, impact, shock, friction etc. In previous theoretical and experimental studies, the sensitivity of RDX is correlated with the strength of trigger bonds. It has been shown that the possible initial reaction mechanisms during the RDX decomposition process are: (1) concerted triple ring fission to produce three methylenenitramine $\left(\mathrm{CH}_{2} \mathrm{NNO}_{2}\right)$ fragments, (2) homolytic $\mathrm{N}-\mathrm{N}$ bond scission, and (3) elimination of HONO. ${ }^{1-6}$ Although there is no conclusive agreement by anyone as to the definitive pathway, the majority of studies ${ }^{3-6}$ indicate that the most probable initial decomposition step for RDX is $\mathrm{N}-\mathrm{N}$ bond homolysis, and $\mathrm{NO}_{2}$ has been identified as a reaction product, since the weakest bond in RDX is the $\mathrm{N}-\mathrm{N}$ bond.

The abovementioned experimental and theoretical work on reaction mechanisms of $\mathrm{RDX}$ is largely restricted to relatively low temperature and pressure regimes. In fact, we observed the temperature and pressure dependent reactions in RDX crystals. Wang et $a .^{7}$ reported that condensed-phase RDX is thermally

${ }^{a}$ State Key Laboratory Cultivation Base for Nonmetal Composites and Functional Materials, Southwest University of Science and Technology, Mianyang 621010, Sichuan, P. R. China. E-mail: genina911@163.com

${ }^{b}$ Laboratory for Shock Wave and Detonation Physics Research, Institute of Fluid Physics, Chinese Academy of Engineering Physics, Mianyang, 621900, P. R. China

${ }^{c}$ Institute of Solid State Physics, Sichuan Normal University, Chengdu 610101, P. R. China decomposed through the elimination of $\mathrm{HNO}_{2}$ under high pressure. It is accompanied by three five-membered ring formations and hydrogen transfer from the $\mathrm{CH}_{2}$ group to the $-\mathrm{NO}_{2}$ group; that is to say, $\mathrm{C}-\mathrm{H}$ bond rupture is involved in the rate-determining step under high pressure. In addition, ultrafast photodecomposition experiments also suggested a very different mechanism for RDX thermal decomposition, where NO was observed as an early reaction product rather than $\mathrm{NO}_{2},{ }^{8,9}$ which is consistent with the result that the initial decomposition of the shocked HMX is triggered by the $\mathrm{N}-\mathrm{O}$ bond breaking. ${ }^{10}$

High shock and collision can also cause the decomposition of condensed-phase RDX in practical applications, with both high temperature and high pressure. The decomposition of energetic materials (EMs) under shock loading can be a criterion to characterize the shock sensitivity. Thus, in order to improve the mechanism for RDX decomposition, understand the initial chemical events induced by shock loading is essential. Based on the time-resolved spectroscopy measurements, the shock decomposition mechanism of RDX reported by Miao et $a{ }^{11}{ }^{11}$ is consistent with the experiment done by Patterson et al., ${ }^{12}$ but the shock under different velocities was not considered. Strachan and Selles ${ }^{2,13}$ studied shock propagation at various velocities based on non-equilibrium molecular dynamics (MD) using the ReaxFF and DPD-RX, respectively. Meantime, the chemical responses of shocked 1,3,5-trinitro1,3,5-triazinane (RDX) crystals were performed by Xue et al. ${ }^{\mathbf{1 4 , 1 5}}$ using the ReaxFF force field combined with the multiscale shock technique. Nevertheless, this method needs larger systems for longer simulations. ${ }^{16,17}$ Recently, Yuan et al. ${ }^{18}$ have studied the initial chemical processes of RDX under shock loading via MD simulations in conjunction with the multi-scale 
shock technique (MSST), nevertheless, shockwave initial decomposition of energetic materials is a complicated physical and chemical process and the fundamental chemical reactions that take place during decomposition is not easily identified.

In our earlier study, the MD simulations in conjunction with the multi-scale shock technique (MSST) has been successfully tested on HMX and has been shown to accurately predict chemical processes. ${ }^{19-21}$ On the basis of previous work, we are also interested in the initial decomposition of RDX under shock loading. We hope that we could further understand the initial chemical reaction under shock loadings and improve the mechanism of RDX decomposition through our work. This paper is organized as follows: the theoretical methods and computational details are given in Sec. II. The results and discussions are presented in Sec. III. The summary of the main results is given in Sec. IV.

\section{Methods and computational details}

In this work, we have performed quantum molecular dynamics simulations in conjunction with the multi-scale shock technique (MSST) in the CP2K software package. ${ }^{22}$ The multi-scale shock technique (MSST) is based on the Navier-Stokes equations for compressible flow. ${ }^{23}$ Instead of simulating a shock wave within a large computational cell with many atoms (the direct approach), the computational cell of the multi-scale technique follows a Lagrangian point through the shock wave, which could be simulated with fewer atoms and lower computational cost. ${ }^{16}$ The multi-scale shock technique simulates steady shock waves (that is, constant shock speed) by the timeevolving equations of motion for atoms and volume of the computational cell to constrain the shock-propagation-vector stress to the Rayleigh line and energy to the Hugoniot relation. For a specified shock speed, the Hugoniot relation $E-E_{0}$ $=1 / 2\left(P+P_{0}\right)\left(V_{0}-V\right)$ could be obtained by the conservation of mass, momentum, and energy across the shock front. ${ }^{24,25}$ Where $E$ is the energy, $P$ is the negative of the diagonal component of the stress tensor in the vector of the shock, and $V$ is the volume. A subscript 0 refers to the pre-shocked state, while quantities without subscripts refer to the post-shocked state. The thermodynamic path connecting the initial state of the system to its final (Hugoniot) state could be described by the Rayleigh line $P-P_{0}=U^{2} \rho_{0}\left(1-\rho_{0} / \rho\right)$ (where $U$ is the shock velocity and $\rho$ is the density). ${ }^{26}$ These two relations describe a steady planar shock wave within continuum theory, which have to obey for steady shock waves.

In this study, the simulation unit cell was taken from the experimentally determined X-ray crystal structure. ${ }^{27}$ It is well known that RDX is an orthorhombic molecular crystals, each RDX molecule consists of 21 atoms, and the unit cell of the RDX crystal contains 8 RDX molecules [Fig. 1(a)]. $\boldsymbol{a}, \boldsymbol{b}, \boldsymbol{c}$ represent the three orthorhombic crystallographic axes of RDX in a space group $P b c a$, respectively. To obtain the equilibrium structure of the unit-cell RDX, the conjugate gradient which has been described in detail in our previous papers ${ }^{19-21}$ was used for the geometry optimization. The wave function was converged to less than $10^{-6}$ a.u. We obtain lattice parameters of $a=12.650 \AA, b=$ $12.0300 \AA, c=10.9609 \AA$ when initial temperature and pressure were set as $300 \mathrm{~K}$ and $0 \mathrm{GPa}$, respectively, which is in good agreement with the experimental values $(a=13.182 \AA, b=$ $11.574 \AA$ A $c=10.9609 \AA) .{ }^{27}$

In our simulation, the simulations cell consists of $24 \mathrm{RDX}$ molecules, corresponding to $3 \times 1 \times 1$ unit cell. We take the shock to be propagating in the $x$ direction. Planar shocks are described by 1D Euler equations so only $\boldsymbol{a}$ is allowed to vary, providing a uniaxial strain condition. In our simulation, the uniaxial compression of the shock wave propagates along the lattice vector $\boldsymbol{a}$ for $37.815 \AA$, (the schematic sketches of the shock compression along the lattice vectors $\boldsymbol{a}$ is shown in Fig. 1(b)). The simulations were performed for shock velocity of $8 \mathrm{~km} \mathrm{~s}^{-1}, 10 \mathrm{~km} \mathrm{~s}^{-1}$ and $11 \mathrm{~km} \mathrm{~s}^{-1}$, respectively, which is below/above the experimentally determined steady detonation shock speed, ${ }^{28,29}$ i.e., about $8.7 \mathrm{~km} \mathrm{~s}^{-1}$. For the shock compression simulations, the fictitious cell mass was set to 1.296 $\times 10^{8}$ a.u. The wave function convergence criteria was $10^{-6} \mathrm{au}$, For the shock speeds $8 \mathrm{~km} \mathrm{~s}^{-1}$, the time step was $0.05 \mathrm{fs}$ for up to $10 \mathrm{ps}$, then for the shock speeds of $10 \mathrm{~km} \mathrm{~s}^{-1}$ and $11 \mathrm{~km} \mathrm{~s}^{-1}$, the time step was 0.05 fs for up to $3.7 \mathrm{ps}$ and $6.9 \mathrm{ps}$, respectively (as shown in Fig. 2). It shows the time-dependence of average temperature, shock-propagation-direction stress and volume rate for shock wave propagates along lattice vectors $\boldsymbol{a}$ at shock velocity $11 \mathrm{~km} \mathrm{~s}^{-1}$. In order to follow the chemical processes as the shock wave propagates through the RDX, we implemented a procedure to identify individual molecules based on bond-length and lifetime criteria in the simulation. This method is also used in the previous literature. ${ }^{19-21,30}$ The configurations were drawn from the trajectory file:

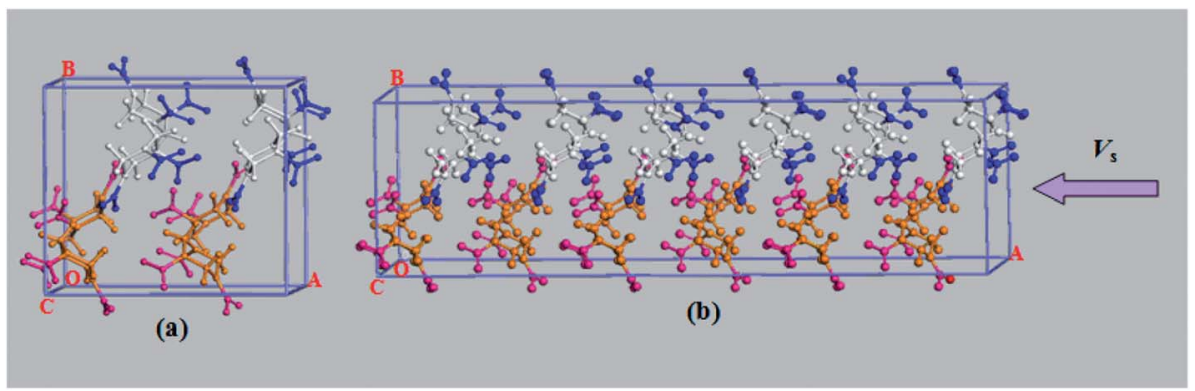

Fig. 1 (a) The unit cell of an RDX crystal contains 8 RDX molecules, which are colored white and orange depending on whether the $\mathrm{NO}_{2}$ groups faces towards (group 1) or faces away (group 2) from the shock plane. The $\mathrm{NO}_{2}$ in group 1 and group 2 molecules are colored in blue and red. (b) Schematic of a planar shock simulation, where $V_{S}$ is shock velocity. 


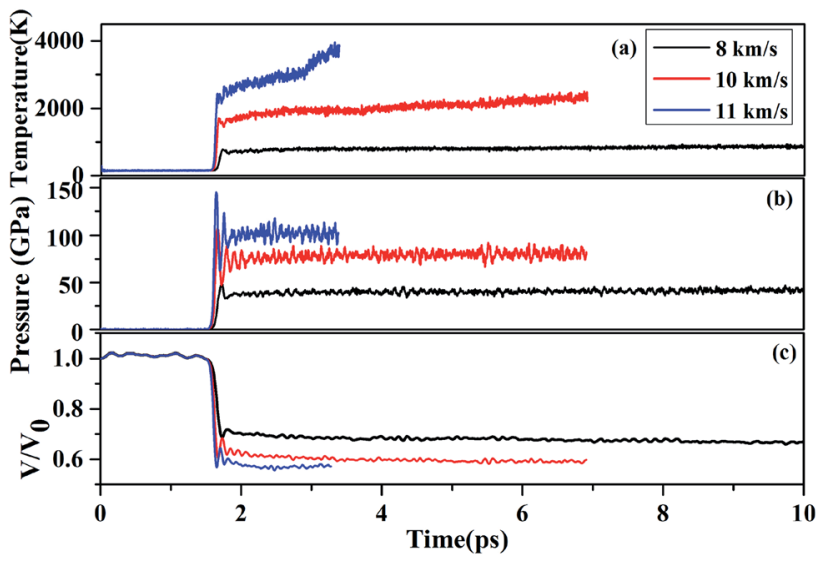

Fig. 2 The time-dependence of average temperature (a), shockpropagation-direction stress (b) and volume rate (c) for shock wave propagates along lattice vectors $a$ at shock velocity $11 \mathrm{~km} \mathrm{~s}^{-1}$.

when two atoms are closer than a given cutoff distance $r_{\mathrm{c}}$ for a time of greater than $100 \mathrm{fs}$, they belong to the same molecule.

\section{Results and discussion}

\subsection{RDX decomposition mechanism}

We perform simulations of the following shock velocities $\left(\mathrm{km} \mathrm{s}^{-1}\right): 8,10$, and 11 , which is near the experimentally measured steady detonation shock speed. During the initial shock compression of condensed-phase RDX under various shock wave, it is found that the $\mathrm{NO}_{2}$ groups facing away from the shock are rather inert to shock loading, whereas, the $\mathrm{NO}_{2}$ groups facing the shock have a dramatic bending due to mechanical deformation and results in the breakage of the chemical bond.
Fig. 3 shows the snapshots of the RDX decomposition reaction for shock velocity $11 \mathrm{~km} \mathrm{~s}^{-1}$ at $1.65 \mathrm{ps}$ and $1.94 \mathrm{ps}$, respectively. It contains $12 \mathrm{RDX}$ molecules, half of them in group 1, and the remaining in group 2. The molecules 1-6 represent group 1 , which presents the $\mathrm{NO}_{2}$ groups faces towards from the shock plane. The molecules 7-12 represent group 2, which presents the $\mathrm{NO}_{2}$ groups faces away from the shock plane. During the initial shock compression, it is found that the group 2 molecules are rather inert to shock loading and reactions are more likely initiated within group 1 molecules. At 1.65 ps, two group 1 molecules decomposed through the $\mathrm{N}-\mathrm{NO}_{2}$ bond dissociation and one group 1 molecule decomposed by $\mathrm{C}-\mathrm{N}$ scission. The initial decomposition products include $\mathrm{NO}_{2}$. However, group 2 molecules only represent a distortion, there is no bond broking. Until at $1.94 \mathrm{ps}$, the group 2 molecules began to decompose, the initial decomposition of shocked RDX is mainly triggered by $\mathrm{C}-\mathrm{N}$ scission, while the group 1 molecules have been decomposed many small fragments.

Compared with group 2 molecules, the group 1 molecules are easier to be decomposed. In fact, the $\mathrm{N}-\mathrm{NO}_{2}$ bond dissociation in group 1 is attributed to mechanical deformation. ${ }^{31,32}$ Fig. 4 shows the $\mathrm{C}_{3}-\mathrm{N}_{1}-\mathrm{N}_{4}, \mathrm{~N}_{5}-\mathrm{N}_{2}-\mathrm{C}_{1}$, and $\mathrm{N}_{6}-\mathrm{N}_{3}-\mathrm{C}_{2}$ bond angles as function of the time under shock loading. Fig. 4(a) shows the time variations of the bond angles in group 2 at shock velocities $11 \mathrm{~km} \mathrm{~s}^{-1}$. It presents that the magnitude of bond angles of group 2 varies in a regular manner around equilibrium point for up to $3.4 \mathrm{ps}$. However, there is an evident change in magnitude of the bond angles $\left(\mathrm{C}_{3}-\mathrm{N}_{1}-\mathrm{N}_{4}\right.$ and $\left.\mathrm{N}_{5}-\mathrm{N}_{2}-\mathrm{C}_{1}\right)$ in group 1 molecules under shock loading, as is shown in Fig. 4(b). The $\mathrm{C}_{3}-\mathrm{N}_{1}-\mathrm{N}_{4}$ and $\mathrm{N}_{5}-\mathrm{N}_{2}-\mathrm{C}_{1}$ easily bent during the dynamical simulation, so that they have a significant decrease in magnitude between the $1.5 \mathrm{ps}$ and $3.4 \mathrm{ps}$. The simulation reveals the coexistence of two qualitatively different molecular responses to shock loading, which indicates group 2 molecules are rather inert to shock loading, in well with the result Nomura ${ }^{33}$

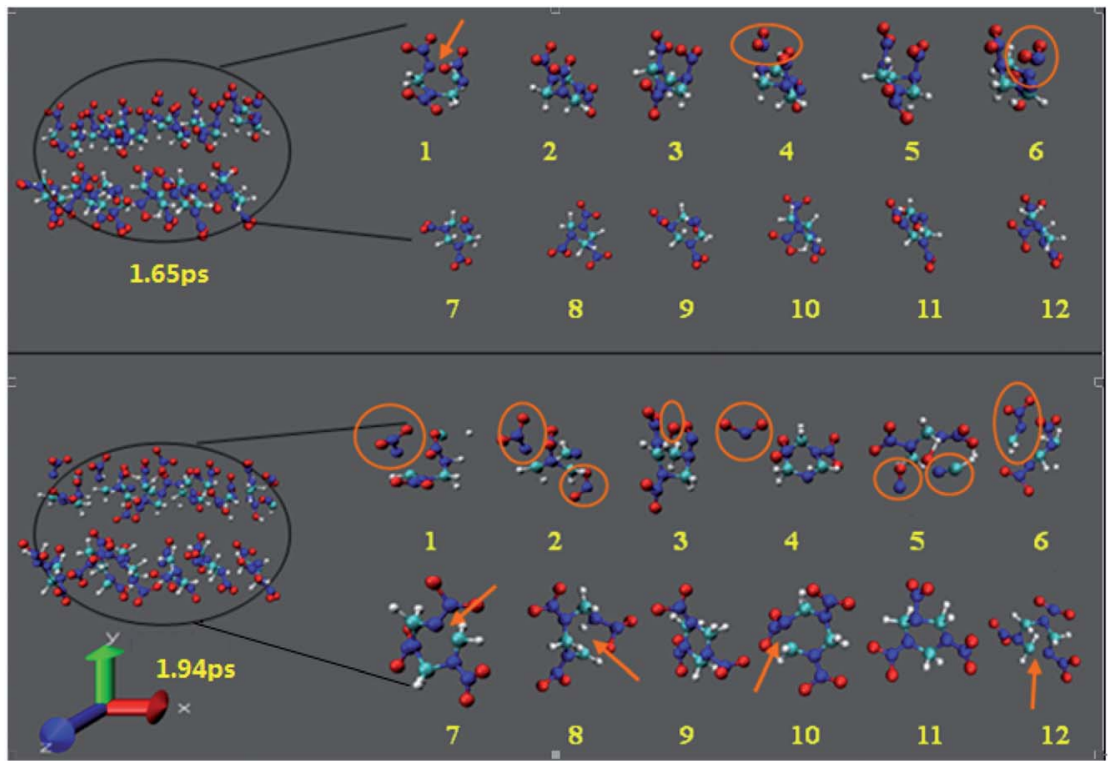

Fig. 3 The snapshots of the RDX decomposition reaction for shock velocity $11 \mathrm{~km} \mathrm{~s}^{-1}$ at $1.65 \mathrm{ps}$ and 1.94 ps, respectively. 

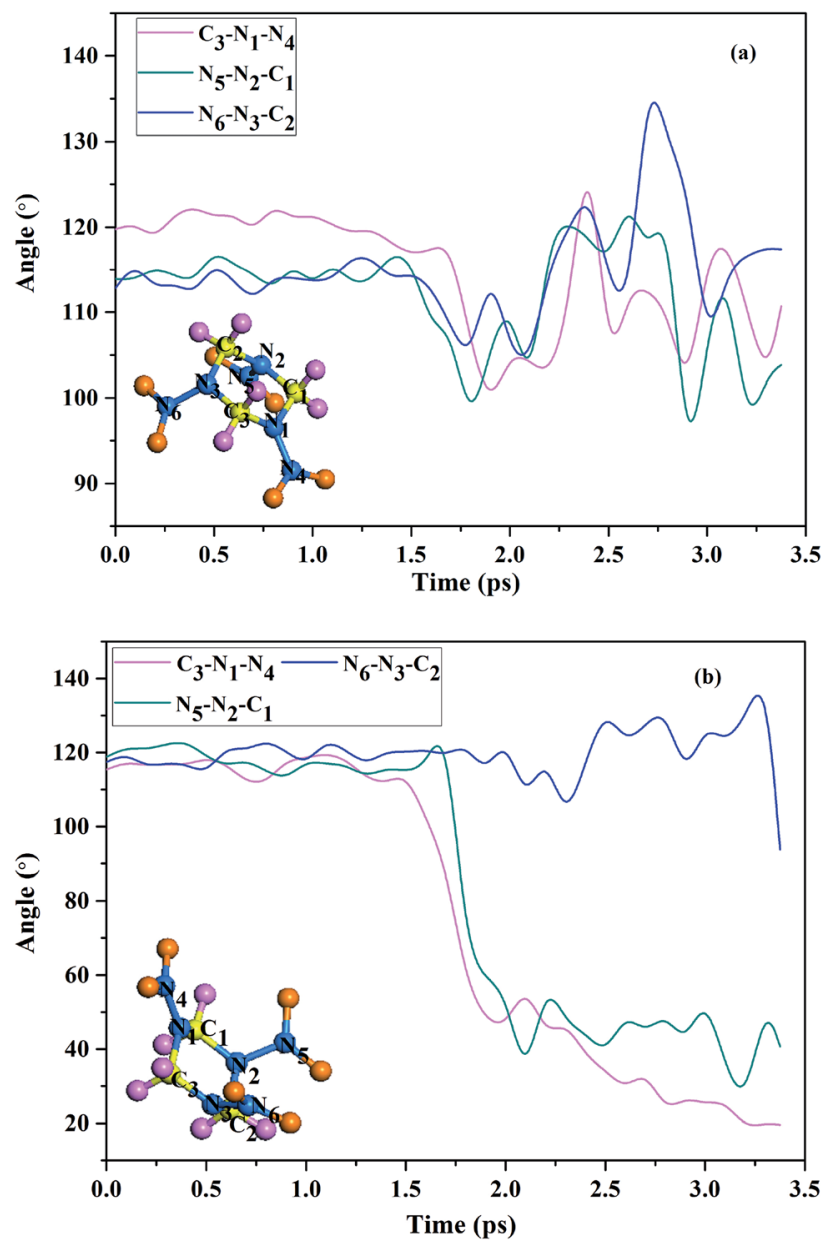

Fig. 4 (a) The $\mathrm{C}_{3}-\mathrm{N}_{1}-\mathrm{N}_{4}, \mathrm{~N}_{5}-\mathrm{N}_{2}-\mathrm{C}_{1}$, and $\mathrm{N}_{6}-\mathrm{N}_{3}-\mathrm{C}_{2}$ bond angles in group 2 as function of the time under shock loading (b) the $C_{3}-N_{1}-N_{4}$, $\mathrm{N}_{5}-\mathrm{N}_{2}-\mathrm{C}_{1}$, and $\mathrm{N}_{6}-\mathrm{N}_{3}-\mathrm{C}_{2}$ bond angles in group 1 as function of the time under shock loading.

calculated with ReaxFF MD. This also reveals that the initial decomposition product of shocked RDX crystal is $\mathrm{NO}_{2}$.

In our present work, we find three distinct initial decomposition channels for RDX in condensed phase under the nohydrostic compression, which is: (1) $\mathrm{N}-\mathrm{NO}_{2}$ bond dissociation, (2) $\mathrm{C}-\mathrm{N}$ bond scission of the ring, and (3) $\mathrm{N}-\mathrm{O}$ bond dissociation. The branching ratios of three primary reaction pathways in this work as shown in Fig. 5. It was shown that both $\mathrm{N}-\mathrm{NO}_{2}$ bond dissociation and $\mathrm{C}-\mathrm{N}$ bond scission of the ring are the dominant primary channels in the initial decomposition.

In order to try to answer is how shock waves trigger chemical reactions, Fig. 6 shows the primary chemical reaction pathways. Actually, the chemical process in condensed phase under the shock loading is very complicated, different RDX molecules experienced various reaction paths under shock loading. In order to make specific analysis of the three distinct decomposition stages, we investigate the molecule where chemical reaction first occurs for three distinct decomposition stages, respectively. They represent three chemical reaction path for shock wave induced decomposition of condense phase RDX.

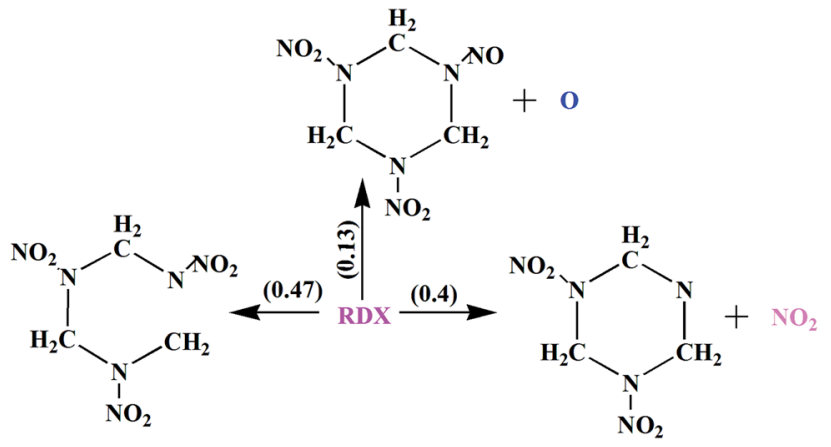

Fig. 5 The branching ratios of three primary reaction pathways.

Reaction 1 leads to the production of $\mathrm{NO}_{2}$, which is one of the dominant primary channels in the initial decomposition under shock loading. In previous experiments, the $\mathrm{NO}_{2}$ has been identified as a reaction product. ${ }^{6,8,34-36}$ In our simulation, it was shown that the initial decomposition of group 1 molecules is mainly triggered by the $\mathrm{N}-\mathrm{NO}_{2}$ bond dissociation. At $1.51 \mathrm{ps,}$ the first vibrations of the nitro group caused a distortion in the RDX: $\mathrm{N}-\mathrm{N}$ bond broke and formed $\mathrm{NO}_{2}$. After that, the $\mathrm{NO}_{2}$ would not be very stable and should undergo further dissociation to smaller more stable species $\mathrm{O}$ and NO (R4). At the same time, many $\mathrm{C}-\mathrm{H}$ bonds were broken, produced many $\mathrm{H}$. As the simulation continued, at $1.85 \mathrm{ps}$, RDX ring was opened through the $\mathrm{C}-\mathrm{N}$ bond scission, forming a long radical chain. At $2.0 \mathrm{ps}$, the long chain further decomposed through reaction (R5) with increasing temperature and pressure, then, the $\mathrm{NO}_{2}, \mathrm{~N}_{2} \mathrm{O}$ and CO combined to generate the short radical chain NCNC, as shown below:

$$
\begin{aligned}
\mathrm{CH}_{2} \mathrm{~N}_{(}\left(\mathrm{NO}_{2}\right) \mathrm{CH}_{2} \mathrm{~N}\left(\mathrm{NO}_{2}\right) \mathrm{CN} \rightarrow & \mathrm{NO}_{2}+\mathrm{N}_{2} \mathrm{O}+\mathrm{CO}+\mathrm{NCNC} \\
& +4 \mathrm{H}
\end{aligned}
$$

$$
\begin{aligned}
& \mathrm{N}_{2} \mathrm{O} \rightarrow \mathrm{N}_{2}+\mathrm{O} \\
& \mathrm{NO}_{2} \rightarrow \mathrm{NO}+\mathrm{O}
\end{aligned}
$$

The $\mathrm{C}-\mathrm{N}$ bond scission is proposed to be favorable in group 2 molecules. Reaction 2 represents that the RDX ring was opened through the $\mathrm{C}-\mathrm{N}$ bond scission and formed a radical chain $\mathrm{CH}_{2} \mathrm{~N}\left(\mathrm{NO}_{2}\right) \mathrm{CH}_{2} \mathrm{~N}\left(\mathrm{NO}_{2}\right) \mathrm{CH}_{2} \mathrm{~N}\left(\mathrm{NO}_{2}\right)$, which is supported by some other experimental studies. ${ }^{6,37}$ It is worth mentioning, Zhao el al. suggested the RDX decomposed into three $\mathrm{CH}_{2} \mathrm{NNO}_{2}$ during the initial decomposition, and the branching ratios of $\mathrm{C}-\mathrm{N}$ is about 0.67 . In this paper, at $1.64 \mathrm{ps}$, the RDX ring was opened though the $\mathrm{C}-\mathrm{N}$ bond scission, forming a long radical chain. At 1.75 ps, C-H bonds and C-N bond were broken, produced two $\mathrm{H}$ and a free $\mathrm{C}$. After that, another $\mathrm{C}-\mathrm{N}$ bond ruptures leading to the elimination of $\mathrm{N}_{2} \mathrm{O}_{2}$. The $\mathrm{N}_{2} \mathrm{O}_{2}$ is a short-lived intermediate, which undergo further decomposition instantaneously by breaking the $\mathrm{N}-\mathrm{O}$ bond to form $\mathrm{N}_{2} \mathrm{O}$, and perhaps that is why the $\mathrm{N}_{2} \mathrm{O}_{2}$ not be observed in experiment. On the other hand, the long chain $\mathrm{CH}_{2} \mathrm{~N}\left(\mathrm{NO}_{2}\right) \mathrm{CH}_{2} \mathrm{~N}\left(\mathrm{NO}_{2}\right)$ further decomposed through reaction (R10) and reaction (R11), respectively, as shown below: 


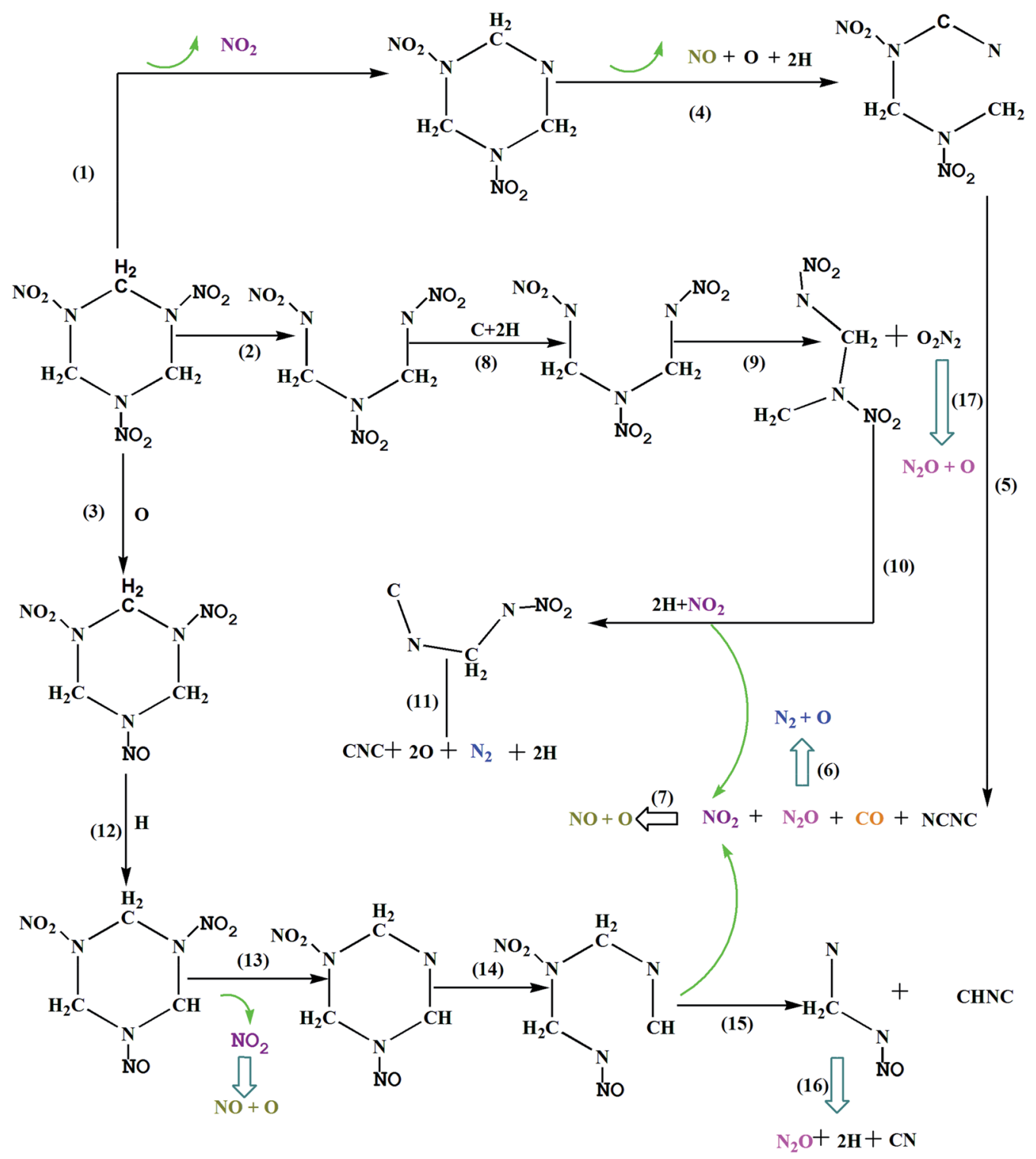

Fig. 6 The decomposition scheme for RDX.

$$
\begin{gathered}
\mathrm{CH}_{2} \mathrm{~N}\left(\mathrm{NO}_{2}\right) \mathrm{CH}_{2} \mathrm{~N}\left(\mathrm{NO}_{2}\right) \rightarrow \mathrm{CNCH}_{2} \mathrm{~N}\left(\mathrm{NO}_{2}\right)+\mathrm{NO}_{2} \\
\mathrm{CNCH}_{2} \mathrm{~N}\left(\mathrm{NO}_{2}\right) \rightarrow \mathrm{CNC}+2 \mathrm{O}+\mathrm{N}_{2}+2 \mathrm{H} \\
\mathrm{N}_{2} \mathrm{O}_{2} \rightarrow \mathrm{N}_{2} \mathrm{O}+\mathrm{O}
\end{gathered}
$$

Reaction 3 shows that the initial decomposition of shock $\mathrm{RDX}$ is triggered by the $\mathrm{N}-\mathrm{O}$ bond breaking at $1.74 \mathrm{ps}$. Then, the $\mathrm{C}-\mathrm{H}$ bond is unstable and break to form a $\mathrm{H}$. As the simulation continued, the $\mathrm{NO}$ and $\mathrm{N}_{2} \mathrm{O}$ can be found in a subsequent reaction. It is evident that pressure accelerates the breaking of $\mathrm{N}-\mathrm{O}$ and $\mathrm{C}-\mathrm{H}$ bonds. The conclusion applies to RDX as well as HMX, $\mathrm{Zhu}^{\mathbf{1 0}}$ suggested that the initial decomposition of shocked HMX was triggered by the $\mathrm{N}-\mathrm{O}$ bond breaking under the impact speed $6.5 \mathrm{~km} \mathrm{~s}^{-1}$. In summary, it is found that the $\mathrm{NO}_{2}$ is observed as one of the major products in almost all these reaction pathways, thus R13 plays a key role in forming $\mathrm{NO}_{2}$.
Once $\mathrm{NO}_{2}$ forms, it can then decompose by breaking the $\mathrm{N}-\mathrm{O}$ bond to form NO (at 1.8 ps). At $1.82 \mathrm{ps}$, the RDX ring was opened by $\mathrm{C}-\mathrm{N}$ bond scission and formed long chain $\mathrm{CHNCH}_{2} \mathrm{~N}\left(\mathrm{NO}_{2}\right)$ $\mathrm{CH}_{2} \mathrm{NNO}$. Finally, the long chain further decomposed and lead to many small molecules, as shown in reaction 15 and 16

$$
\begin{aligned}
& \mathrm{CHNCH}_{2} \mathrm{~N}\left(\mathrm{NO}_{2}\right) \mathrm{CH}_{2} \mathrm{NNO} \rightarrow \mathrm{NCH}_{2} \mathrm{NNO}+\mathrm{CHNC}+\mathrm{NO}_{2} \\
& \mathrm{NCH}_{2} \mathrm{NNO} \rightarrow \mathrm{N}_{2} \mathrm{O}+2 \mathrm{H}+\mathrm{CN}
\end{aligned}
$$

As already mentioned above, we present the major decomposition pathway under shock loading. Experimentally observed small mass fragments such as $\mathrm{NO}_{2}, \mathrm{~N}_{2} \mathrm{O}$, $\mathrm{NO}$ and $\mathrm{N}_{2}$ can be explained based on our scheme. Other small mass fragments detected experimentally such as $\mathrm{H}_{2} \mathrm{O}, \mathrm{CO}$ and $\mathrm{CO}_{2}$ are also be found as an important major species under high temperature and pressure. The related chemical pathways are: 


$$
\begin{gathered}
\mathrm{H}+\mathrm{H} \rightarrow \mathrm{H}_{2} \\
\mathrm{OH}+\mathrm{H} \rightarrow \mathrm{H}_{2} \mathrm{O} \\
\mathrm{C}+\mathrm{O} \rightarrow \mathrm{CO} \\
\mathrm{C}+2 \mathrm{O} \rightarrow \mathrm{CO}_{2}
\end{gathered}
$$

Under extreme condition, there are many number of free $\mathrm{H}$. Some free $\mathrm{H}$ combined to form $\mathrm{H}_{2}$ via $\mathrm{R} 18$, but most as free $\mathrm{H}$ ions play an important role during the initial decompression progress which will enhance chemical reaction of energetic material RDX. There are many free $\mathrm{OH}$, which has been extensively considered as the major decomposition products in both the thermal decomposition and the shock decomposition of all energetic material. This is also considered as the basis for formation of water molecules, as shown in R19. In addition, such as $\mathrm{CO}$ and $\mathrm{CO}_{2}$, which are common reaction products in the previously theoretical simulation and experimental studies, results from related chemical pathways R20 and R21.

\subsection{Species analysis under impact loading conditions}

In Fig. 7, we shown the time evolution of the population of various key fragments $\left(\mathrm{H}_{2}, \mathrm{~N}_{2}, \mathrm{H}_{2} \mathrm{O}, \mathrm{N}_{2} \mathrm{O}, \mathrm{NO}, \mathrm{NO}_{2}, \mathrm{CO}\right.$ and $\left.\mathrm{CO}_{2}\right)$ from $V_{\mathrm{S}}=$ 8 to $11 \mathrm{~km} \mathrm{~s}^{-1}$. For $V_{\mathrm{S}}=8 \mathrm{~km} \mathrm{~s}^{-1}$, there were little chemical reactions, only $\sim 2 \mathrm{NO}_{2}, \sim 1 \mathrm{~N}_{2} \mathrm{O}$ and $\sim 1 \mathrm{NO}$ were formed during the course of simulation, as shown in Fig. 7(a). Dobratz and Crawford $^{29}$ have reported the limiting detonation velocity is 8.639 $\mathrm{km} \mathrm{s}^{-1}$ for RDX, above our shock velocity, and perhaps that is why there were little chemical reactions. The $\mathrm{NO}_{2}$ has been identified as the first reaction product and the number of $\mathrm{NO}_{2}$ is much larger than that of $\mathrm{N}_{2} \mathrm{O}$ and $\mathrm{NO}$, which suggested that the $\mathrm{N}-\mathrm{N}$ bond homolysis is the first decomposition step. This is consistent with the previous theoretical and experimental results. ${ }^{2,34,35,38,39}$

Compared with $V_{\mathrm{S}}=8 \mathrm{~km} \mathrm{~s}^{-1}$, the decomposition process had a significantly enhancement in $V_{\mathrm{S}}=10 \mathrm{~km} \mathrm{~s}^{-1}$. Fig. 7(b) shows the time evolution of the population of key molecules at the $V_{\mathrm{S}}=10 \mathrm{~km} \mathrm{~s}^{-1}$, which RDX further decomposed. During the early stage (up to $\sim 4 \mathrm{ps}$ ), the $\mathrm{NO}_{2}$ is also be identified as the first reaction product, moreover, the dominant molecules include $\mathrm{NO}_{2}, \mathrm{~N}_{2} \mathrm{O}$, and NO. After the time $\sim 4 \mathrm{ps}$, the number of the $\mathrm{NO}_{2}$ decreased with the increasing time, but in contrast $\mathrm{N}_{2} \mathrm{O}$ and NO increased significantly with the increasing time. Compared with the products at the $V s=8 \mathrm{~km} \mathrm{~s}^{-1}$, It is worth noting that there are some new reaction products at $10 \mathrm{~km} \mathrm{~s}^{-1}$, such as $\mathrm{N}_{2}, \mathrm{CO}$, $\mathrm{H}_{2} \mathrm{O}$ and $\mathrm{CO}_{2}$ which are common reaction products in the previously theoretical simulation ${ }^{\mathbf{2 , 4 0 - 4 2}}$ and experimental studies. ${ }^{\mathbf{8 , 4 3 , 4 4}}$ The dominant reaction products of the $\mathrm{N}_{2}$ and $\mathrm{CO}$ have a dramatic increasing with time (from the time $\sim 4 \mathrm{ps}$ ). $\mathrm{H}_{2} \mathrm{O}, \mathrm{H}_{2}$ and $\mathrm{CO}_{2}$ are formed after the appearance of $\mathrm{NO}_{2}, \mathrm{NO}$, $\mathrm{N}_{2} \mathrm{O}, \mathrm{N}_{2}$ and CO. For $\mathrm{H}_{2} \mathrm{O}$, it increases with the time (after time 5 $\mathrm{ps}$ ), and reached a maximum value at $6.5 \mathrm{ps}$. Compared with other small fragments, the amounts of $\mathrm{H}_{2}$ and $\mathrm{CO}_{2}$ were smaller and the $\mathrm{CO}_{2}$ reached a final balance.

At $V_{\mathrm{S}}=11 \mathrm{~km} \mathrm{~s}^{-1}$ shock velocity, there were a larger quantity of $\mathrm{CO}(\sim 23), \mathrm{N}_{2}(\sim 24)$, $\mathrm{NO}(\sim 12), \mathrm{N}_{2} \mathrm{O}(\sim 6)$ and $\mathrm{CO}_{2}(\sim 4)$ in the expansion stage (Fig. 6(c)). As the impact velocity increases, we

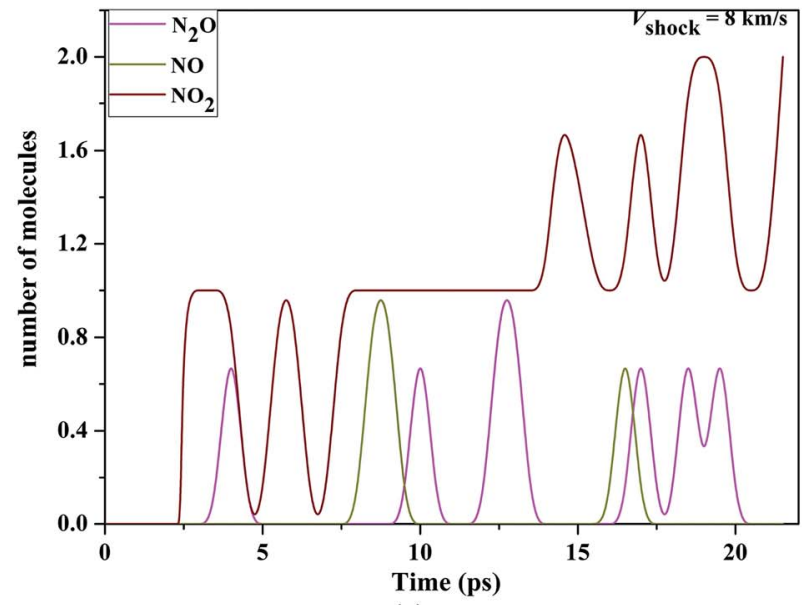

(a)

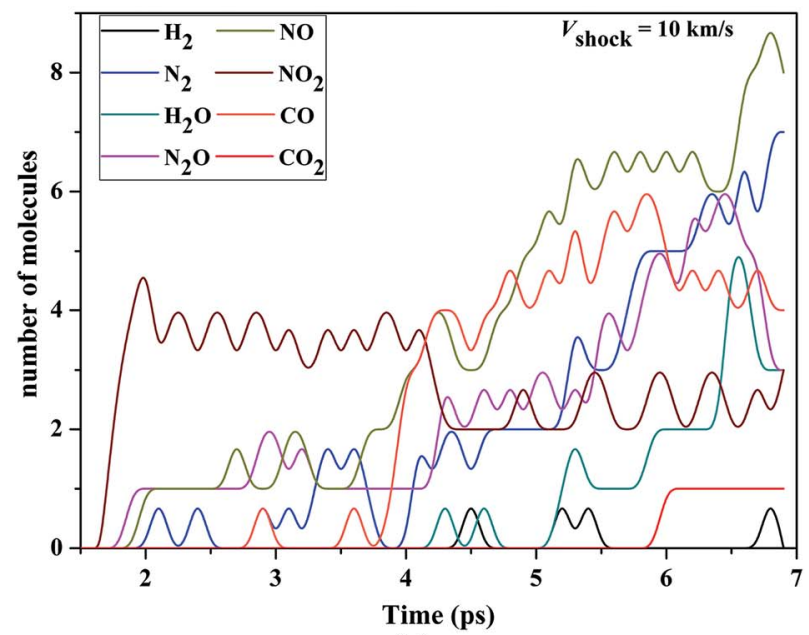

(b)

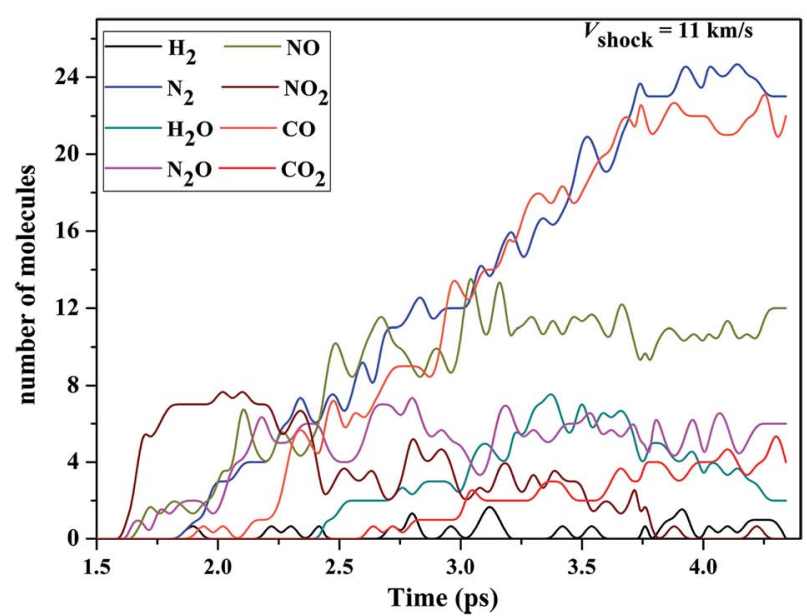

(c)

Fig. 7 (a) Decomposition products of condensed-phase RDX under the various shock velocities $8 \mathrm{~km} \mathrm{~s}^{-1}$. (b) Decomposition products of condensed-phase RDX under the various shock velocities $10 \mathrm{~km} \mathrm{~s}^{-1}$. (c) Decomposition products of condensed-phase RDX under the various shock velocities $11 \mathrm{~km} \mathrm{~s}^{-1}$.

found the significant reaction intermediate at very early stage was still $\mathrm{NO}_{2}$, which was said to result from $\mathrm{N}-\mathrm{NO}_{2}$ bond breakage in the initial stages of shock detonation. So, we think 
that the initial step of decomposition was the homolysis of $\mathrm{N}-$ $\mathrm{NO}_{2}$ bond both under weak and strong shock compression. Most notably, the dominant reaction product is $\mathrm{NO}_{2}$ at very early stage, whose population reached a maximum value at 2.0 ps and then decreased with increasing time thereafter. The amounts of the $\mathrm{NO}, \mathrm{CO}$ and $\mathrm{N}_{2}$ were larger than other products during the expansion stage in shock velocity $10 \mathrm{~km} \mathrm{~s}^{-1}$, however, with the increasing shock velocity, the amounts of the $\mathrm{H}_{2}, \mathrm{~N}_{2}$ and $\mathrm{CO}$ were larger than other products during the expansion stage. These present that the populations of $\mathrm{H}_{2}, \mathrm{~N}_{2}$ and $\mathrm{CO}$ (NO) increase (decreases) significantly with the increasing shock velocity. In addition, compared with the shock velocity $10 \mathrm{~km} \mathrm{~s}^{-1}$, the population of the $\mathrm{N}_{2} \mathrm{O}, \mathrm{H}_{2} \mathrm{O}$ and $\mathrm{CO}$ had a significantly increasing in shock velocity $11 \mathrm{~km} \mathrm{~s}^{-1}$ and reached a final balance.

During the detonation, the shockwave passed through the material and generated high pressures and temperatures. By summarizing our current and other previous work, we found that the decomposition pathway of nitramines and nitrosamines are closed related to the pressure and temperature of system upon shock loading. From Fig. 7, it can be seen that the most reactive gases were still the $\mathrm{NO}_{2}$ at early stage in shock velocity $10 \mathrm{~km} \mathrm{~s}^{-1}$ and $11 \mathrm{~km} \mathrm{~s}^{-1}$. Then, with increasing time, it can be seen that the global nitrogen schemes of $\mathrm{NO}_{2} \rightarrow$ $\mathrm{NO}\left(\mathrm{N}_{2} \mathrm{O}\right) \rightarrow \mathrm{N}_{2}$ was the final steady production pathway at higher pressure and high temperature, i.e., the $\mathrm{NO}, \mathrm{N}_{2} \mathrm{O}$ decreasing extent with the $\mathrm{N}_{2}$ reached to a greater with increasing shock velocity.

\subsection{Pair correlation functions (PCFs) of the RDX with the different impact velocity}

To clarify the structural change of the HMX under shock conditions, we calculated the pair correlation functions (PCFs) for each pair of atom types, which give probability of finding an atom of a given type at a given distance from a reference atom. The PCFs of the CO, $\mathrm{CO}_{2}, \mathrm{~N}_{2}, \mathrm{~N}_{2} \mathrm{O}, \mathrm{H}_{2} \mathrm{O}$ and $\mathrm{NO}$ for $V_{\mathrm{imp}}=10 \mathrm{~km}$ $\mathrm{s}^{-1}$ and $V_{\text {imp }}=11 \mathrm{~km} \mathrm{~s}^{-1}$ are presented in Fig. 8, respectively. It is commonly considered that the $\mathrm{C}-\mathrm{O}$ bond in $\mathrm{CO}\left(\mathrm{CO}_{2}\right)$ molecule, $\mathrm{H}-\mathrm{O}$ bond in $\mathrm{H}_{2} \mathrm{O}$ molecule, $\mathrm{N}-\mathrm{N}$ bond in $\mathrm{N}_{2}$ (or $\mathrm{N}_{2} \mathrm{O}$ ) molecule, as well as $\mathrm{N}-\mathrm{O}$ bond in $\mathrm{NO}$ (or $\mathrm{N}_{2} \mathrm{O}$ ) are approximate to $1.13 \AA$ (or $1.16 \AA$ ), $1.0 \AA$, $1.42 \AA$ (or $1.186 \AA$ ) and $1.15 \AA$, respectively. From Fig. $8(\mathrm{a})$, it can be seen that compared with $\mathrm{g}_{\mathrm{C}-\mathrm{O}}(\mathrm{r})$ for $10 \mathrm{~km} \mathrm{~s}^{-1}$ the height of peaks increase at 1.14 and $3.45 \AA$ and decrease at $2.75 \AA$. The peak of $\mathrm{C}-\mathrm{O}$ PCFs $\mathrm{g}_{\mathrm{C}-\mathrm{O}}(\mathrm{r})$ locates around $1.14 \AA$, which suggests that the $\mathrm{C}-\mathrm{O}$ distribution is the mixture of the $\mathrm{CO}$ and $\mathrm{CO}_{2}$. The maximum of the PCFs $\mathrm{g}_{\mathrm{C}-}$ $o(r)$ for $11 \mathrm{~km} \mathrm{~s}^{-1}$ is larger than that for $10 \mathrm{~km} \mathrm{~s}^{-1}$, which indicates the number of $\mathrm{CO}\left(\mathrm{CO}_{2}\right)$ increase with increasing temperature. This is consistent well with preceding study about species analysis for $V_{\mathrm{S}}=10 \mathrm{~km} \mathrm{~s}^{-1}$ and $V_{\mathrm{S}}=11 \mathrm{~km} \mathrm{~s}^{-1}$. From Fig. 8(b), the maximum of the PCFs $g_{N-N}(r)$ for $10 \mathrm{~km} \mathrm{~s}^{-1}$ is larger than that for $11 \mathrm{~km} \mathrm{~s}^{-1}$, since part of the $\mathrm{N}-\mathrm{NO}_{2}$ bond have not been dissociated. With the increase of the shock velocity, the main peak of PCF $\mathrm{g}_{\mathrm{N}-\mathrm{N}}(\mathrm{r})$ becomes reduced in amplitude due to the $\mathrm{N}-\mathrm{NO}_{2}$ bond further dissociated. Fig. 8(c) presents the radial distribution function for $\mathrm{O}-\mathrm{H}$ atoms pairs, It
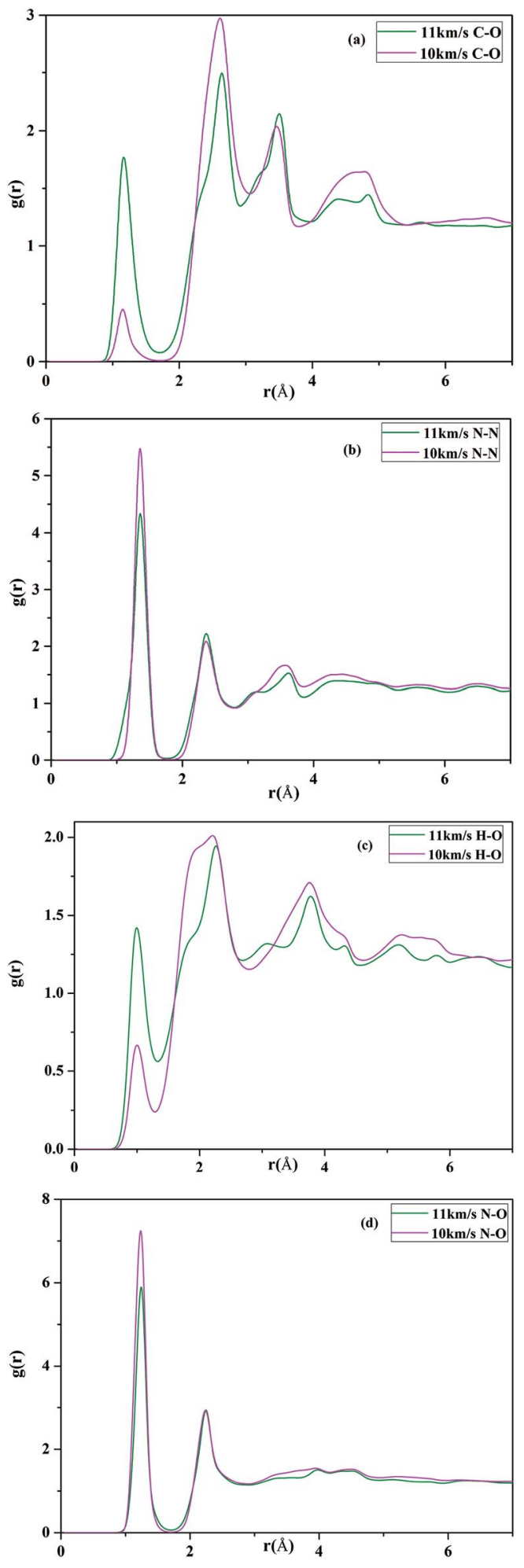

Fig. 8 Calculated pair radial distribution functions under shock velocities $10 \mathrm{~km} \mathrm{~s}^{-1}$ and $11 \mathrm{~km} \mathrm{~s}^{-1}$ : (a) $\mathrm{C}-\mathrm{O}$; (b) N-N; (c) $\mathrm{H}-\mathrm{O}$; (d) N-O.

can be seen that $\mathrm{g}_{\mathrm{H}-\mathrm{O}}(\mathrm{r})$ around $1.0 \AA$ appears a maximum peak, which indicates $\mathrm{H}_{2} \mathrm{O}$ molecules are form and also presents that the number of the water will increase when the shock velocity passed through the material with $11 \mathrm{~km} \mathrm{~s}^{-1}$. At the same time, $\mathrm{N}-\mathrm{O}$ bond length locates around $1.2 \AA$ at $10 \mathrm{~km} \mathrm{~s}^{-1}$ and $11 \mathrm{~km}$ 
$\mathrm{s}^{-1}$, respectively, which is close to the value of nitrogen oxide, nitrous oxide, as shown in Fig. 8(d). The above analysis again suggest that decomposition of RDX generates small molecules $\mathrm{CO}, \mathrm{CO}_{2}, \mathrm{H}_{2} \mathrm{O}, \mathrm{NO}_{2}$, $\mathrm{NO}$ and $\mathrm{N}_{2} \mathrm{O}$ under the $10 \mathrm{~km} \mathrm{~s}^{-1}$ and $11 \mathrm{~km}$ $\mathrm{s}^{-1}$ velocity impact.

\section{Conclusions}

We have performed molecular dynamics simulations in conjunction with the multiscale shock technique (MSST) to study the initial chemical processes of condensed-phase RDX under shock wave loading. A self-consistent charge density functional tight-binding (SCC-DFTB) method was used. We find that the $\mathrm{N}-\mathrm{NO}_{2}$ bond dissociation is the primary pathway for $\mathrm{RDX}$ with the $\mathrm{NO}_{2}$ groups facing (group 1) the shock, whereas the $\mathrm{C}-\mathrm{N}$ bond scission is the dominant primary channel for RDX with the $\mathrm{NO}_{2}$ groups facing away from (group 2) the shock. Moreover, our results present the $\mathrm{NO}_{2}$ groups facing away from the shock are rather inert to shock loading. It was indicated that the initial step was the $\mathrm{N}-\mathrm{N}$ bonds dissipation under the $8 \mathrm{~km}$ $\mathrm{s}^{-1}, 10 \mathrm{~km} \mathrm{~s}^{-1}$ and $11 \mathrm{~km} \mathrm{~s}^{-1}$ shock velocities. The gaseous products such as $\mathrm{NO}_{2}, \mathrm{NO}$ and $\mathrm{N}_{2} \mathrm{O}$ can be identified under 8 $\mathrm{km} \mathrm{s} \mathrm{s}^{-1}$, but with a little amounts. As the shock velocity increases, the decomposition process had a significantly enhancement, $\mathrm{NO}_{2}, \mathrm{NO}, \mathrm{N}_{2} \mathrm{O}, \mathrm{H}_{2} \mathrm{O}, \mathrm{CO}, \mathrm{CO}_{2}$ and $\mathrm{N}_{2}$ were the main products under the $10 \mathrm{~km} \mathrm{~s}^{-1}$ and $11 \mathrm{~km} \mathrm{~s}^{-1}$. The populations of $\mathrm{N}_{2}, \mathrm{~N}_{2} \mathrm{O}, \mathrm{H}_{2} \mathrm{O}$ and $\mathrm{CO}$ had a significantly increasing with the increasing shock velocity, while that of NO decreases significantly with the increasing shock velocity.

\section{Conflicts of interest}

There are no conflicts to declare.

\section{Acknowledgements}

The authors would acknowledge the National Natural Science Foundation of China (Grant No. 11504304 and 11304211), the Open Project of State Key Laboratory Cultivation Base for Nonmetal Composites and Functional Materials (15zxfk08) and Funded by Longshan academic talent research supporting program of SWUST No. 17LZX674, Supported by Sichuan Science and Technology Program 2018 GZ0333 and 2017TD0020. Science Challenging Program JCKY2016212A501.

\section{References}

1 J. P. Lewis, K. R. Glaesemann, K. V. Opdorp and G. A. Voth, J. Phys. Chem. A, 2000, 104, 11384-11389.

2 A. Strachan, A. C. T. van Duin, D. Chakraborty, S. D. Dasgupta and W. A. Goddard III, Phys. Rev. Lett., 2003, 91, 098301.

3 T. R. Botcher and C. A. Wight, J. Phys. Chem., 1994, 98, 54415444.

4 T. R. Botcher and C. A. Wight, J. Phys. Chem., 1993, 97, 91499153.
5 C. A. Wight and T. R. Botcher, J. Am. Chem. Soc., 1992, 114, 8303-8304.

6 X. S. Zhao, E. J. Hintsa and Y. T. Lee, J. Chem. Phys., 1988, 88, 801-810.

7 J. Wang, K. R. Brower and D. L. Naud, J. Org. Chem., 1997, 62, 9055-9060.

8 M. Greenfield, Y. Q. Guo and E. R. Bernstein, Chem. Phys. Lett., 2006, 430, 277.

9 Y. Q. Guo, M. Greenfield and E. R. Bernsteina, J. Chem. Phys., 2005, 122, 244310.

10 W. H. Zhu and H. Huang, J. Chem. Phys., 2012, 136, 044516.

11 M. S. Miao, Z. A. Dreger, J. E. Patterson and Y. M. Gupta, J. Phys. Chem. A, 2008, 112, 7383.

12 J. E. Patterson, Z. A. Dreger, M. S. Miao and Y. M. Gupta, J. Phys. Chem. A, 2008, 112, 7374.

13 M. S. Sellers, M. Lísal, I. Schweigert, J. P. Larentzos and J. K. Brennan, in AIP Conference Proceedings, 2017, vol. 1793, p. 040008.

14 X. G. Xue, Y. S. Wen, X. P. Long, J. S. Li and C. Y. Zhang, J. Phys. Chem. C, 2015, 119, 13735-13742.

15 Y. Li, R. K. Kalia, A. Nakano and P. Vashishta. in AIP Conference Proceedings, 2017, vol. 1793, p. 030007.

16 K. Kadau, T. C. Germann, P. S. Lomdahl and B. L. Holian, Science, 2002, 296, 1681.

17 J. D. Kress, S. R. Bickham, L. A. Collins, B. L. Holian and S. Goedecker, Phys. Rev. Lett., 1999, 83, 3896.

18 J. N. Yuan, Y. K. Wei, X. Q. Zhang, X. R. Chen, G. F. Ji, M. K. Kotni and D. Q. Wei, J. Appl. Phys., 2017, 122, 135901.

19 N. N. Ge, Y. K. Wei, G. F. Ji, X. R.Cheng, F. Zhao and D. Q. Wei, J. Phys. Chem. B, 2012, 116, 13696-13704.

20 N. N. Ge, Y. K. Wei, Z. F. Song, X. R.Cheng, G. F. Ji, F. Zhao and D. Q. Wei, J. Phys. Chem. B, 2014, 118, 8691-8699.

21 N. N. Ge, Y. K. Wei, F. Zhao, X. R.Cheng and G. F. Ji, J. Mol. Model., 2014, 20, 2350.

22 The CP2K developers group, http://cp2k.berlios.de/, 2007.

23 E. J. Reed, L. E. Fried and J. D. Joannopoulos, Phys. Rev. Lett., 2003, 90, 235503.

24 N. Goldman, E. J. Reed, I. F. W. Kuo, L. E. Fried, C. J. Mundy and A. Curioni, J. Chem. Phys., 2009, 130, 124517.

25 C. J. Mundy, A. Curioni, N. Goldman and I. F. W. Kuo, J. Chem. Phys., 2008, 128, 184701.

26 E. J. Reed, M. R. Manaa, L. E. Fried and K. R. A. Glaesemann, Nat. Phys., 2008, 4, 72-76.

27 C. S. Choi and E. Prince, Acta Crystallogr. Sect.B, 1972, 28, 2857.

28 C. L. Mader, Numerical Modeling of Water Waves, CRC Press, Boca Raton, 1998, p. 55.

29 B. M. Dobratz and P. C. Crawford, LLNL Explosives Handbook, Lawrence Livermore National Laboratory, University of California, 1985.

30 M. R. Manaa, E. J. Reed, L. E. Fried and N. Goldman, J. Am. Chem. Soc., 2009, 131, 5483-5487.

31 Q. Cui, M. Elstner, E. Kaxiras, T. Frauenheim and M. Karplus, J. Phys. Chem. B, 2001, 105, 569-585.

32 M. R. Manaa, L. E. Fried, C. F. Melius, M. Elstner and T. Frauenheim, J. Phys. Chem. A, 2002, 106, 9024-9029. 
33 K. I. Nomura, R. K. Kalia, A. Nakano and P. Vashishta, Phys. Rev. Lett., 2007, 99, 148303.

34 T. R. Botcher and C. A. Wight, J. Phys. Chem., 1994, 98, 5441. 35 F. J. Owens and J. Sharmar, J. Appl. Phys., 1980, 51, 14941979.

36 M. D. Pace and W. B. Moniz, J. Magn. Reson., 1969, 47, 510.

37 T. B. Brill, H. Arisawa, P. J. Brush, P. E. Gongwer and G. K. Williams, J. Phys. Chem., 1995, 999, 1384.

38 G. F. Adams and R. W. Shaw, Annu. Rev. Phys. Chem., 1992, 43, 311 .
39 N. J. Harris and K. Lammertsma, J. Am. Chem. Soc., 1997, 119, 6583.

40 Z. H. Yan, W. Liu, C. C. Zhang, X. M. Wang, J. S. Li and Z. W. Yang, J. Hazard. Mater., 2016, 313, 103-111.

41 D. Z. Guo, S. V. Zybin, Q. An, W. A. Goddard III and F. L. Huang, Phys. Chem. Chem. Phys., 2016, 18, 2015-2022.

42 H. Muthurajan, R. Sivabalan, M. B. Talawar and S. N. Asthana, J. Hazard. Mater., 2004, 112, 17-33.

43 S. H. Kim, B. W. Nyande, H. S. Kim, J. S. Park and W. J. Lee, J. Hazard. Mater., 2016, 308, 120-130.

44 Y. Oyumi and T. B. Brill, Combust. Flame, 1985, 62, 213-224. 